\title{
Bleeding complications of intracoronary fibrinolytic therapy in acute myocardial infarction Assessment of risk in a randomised trial
}

\author{
FREEK W A VERHEUGT, MACHIEL J VAN EENIGE, JAN C J RES, \\ MAARTEN L SIMOONS, PATRICK W SERRUYS, FRANK VERMEER, \\ DIEDERIK C A VAN HOOGENHUYZE, PIM J REMME, CHRIS DE ZWAAN, \\ FRITS BAER
}

From the Interuniversity Cardiology Institute, the Netherlands

SUMMARY The risk of bleeding associated with intracoronary infusion of streptokinase in acute myocardial infarction was determined in a randomised controlled trial containing 302 patients under the age of 70 . Intracoronary streptokinase infusion was given to 152 patients and 150 patients were treated conventionally. Bleeding was seen in $24(16 \%)$ patients in the streptokinase group and in two of the conventionally treated patients. Bleeding was most common (28\%) in patients over the age of 60 years. The groin was the site of bleeding in all patients except one. In the first 48 hours after admission the haematocrit in streptokinase treated patients with manifest bleeding fell by $0.07(0.04)$ (mean (SD)). The fall in haematocrit in the streptokinase treated patients without manifest bleeding was $0.05(0.04)$ and in the conventionally treated patients it fell by $0.03(0.04)$. Sixty six units of packed cells were transfused in the streptokinase group (50 units to those who bled); the control group required only 17 units. There were no deaths due to bleeding. The occurrence of bleeding and the fall in haematocrit in the streptokinase group correlated with the occurrence of systemic fibrinolysis but not with the dose of streptokinase given.

Thus, in about $15 \%$ of patients treatment with intracoronary streptokinase resulted in significant non-fatal bleeding from the femoral puncture site that required substantial transfusion support. Furthermore, there was a significant drop in haematocrit in patients without manifest bleeding. These results emphasise the need for more specific fibrinolytic agents.

Streptokinase is an effective thrombolytic agent in arterial and venous thrombotic disease. ${ }^{12}$ It can, however, produce massive, and potentially fatal bleeding due to systemic breakdown of fibrinogen and other clotting factors. Techniques of selective intra-arterial administration have been developed in an attempt to prevent such bleeding.

Intracoronary infusion of streptokinase in acute myocardial infarction has been shown to reduce infarct size $^{34}$ and preservation of left ventricular function ${ }^{45}$ and improvement in six month mortality ${ }^{4}$ have been reported. Although selective

Requests for reprints to Dr Freek W A Verheugt, Department of Cardiology, Free University Hospital, De Boelelaan 1117, 1007 MB Amsterdam, the Netherlands.

Accepted for publication 12 July 1985 thrombolysis with low dose streptokinase was very effective in achieving reperfusion of occluded coronary arteries, systemic fibrinolysis was common. ${ }^{6-9}$ The combination of intra-arterial instrumentation and systemic fibrinolysis when streptokinase is given by the intracoronary route may promote serious bleeding complications in acutely ill patients with myocardial infarction.

We analysed the risk of bleeding associated with intracoronary streptokinase treatment in acute myocardial infarction in a randomised multicentre study.

\section{Patients and methods}

The following four hospitals participated in a multicentre study in the Netherlands: Thoraxcenter, Dijkzigt Hospital, Rotterdam; Free University 
Hospital, Amsterdam; Zuiderziekenhuis, Rotterdam; and Annadal Hospital, Maastricht. Between May 1981 and December 1983, 302 patients who met the following criteria entered the trial: $(a)$ typical history and symptoms of acute myocardial infarction within 4 hours of admission; (b) electrocardiographic changes typical of acute transmural myocardial infarction (that is, ST elevation in the standard leads of $\geqslant 0.1 \mathrm{mV}$ or ST elevation of $\geqslant 0.2 \mathrm{mV}$ in the precordial leads); (c) age $\leqslant 70$ years; (d) absence of earlier streptokinase treatment, coronary bypass operation in the area infarcted at admission, recent trauma, prolonged cardiac massage, menorrhagia, pregnancy, unconsciousness, active gastric ulcer, haematuria, or stroke. Data on the patients at admission are given in Table 1. After admission to the study the patients were randomly allocated to either intracoronary streptokinase treatment $(n=152)$ or conventional treatment $(n=150)$. Informed consent was obtained from patients randomised to the streptokinase group. They underwent coronary arteriography by the transfemoral (Judkins) route through a French 7 introducer sheath. An intravenous bolus injection of $250 \mathrm{mg}$ acetylsalicylic acid, $100 \mathrm{mg}$ hydrocortisone, and 5000 units of heparin was then given. In patients in whom the infarct related coronary artery was occluded, intracoronary streptokinase was infused at a rate of 4000 units per minute. Coronary arteriography was repeated every 15 minutes to check whether reperfusion had taken place. After reperfusion, if any, the infusion of streptokinase was continued for at least 15 minutes. Intracoronary streptokinase infusion was limited to a maximum of 60 minutes corresponding to a maximum dose of 250000 units. When the infarct related coronary artery was patent on the first arteriogram, the artery was perfused with 4000 units of streptokinase per minute for 15 minutes. A left ventricular cine-

Table 1 Characteristics mean (SD) of patients before randomisation

\begin{tabular}{|c|c|c|}
\hline & Streptokinase & Control \\
\hline $\begin{array}{l}\text { No of patients } \\
\text { Sex }(\% \text { male) } \\
\text { Age }(\mathrm{yr}) \\
\text { Use of oral anticoagulants } \\
\text { Use of antiplatelet drugs } \\
\text { Resuscitated } \\
\text { Systolic blood pressure (mm Hg) } \\
\text { Diastolic blood pressure }(\mathrm{mm} \mathrm{Hg}) \\
\text { Heart rate (beats/min) } \\
\text { Haemoglobin }(\mathrm{mmol} / \mathrm{l}) \\
\text { Haematocrit } \\
\text { Lactate dehydrogenase }(\mathrm{U} / \mathrm{l})\end{array}$ & $\begin{array}{l}152 \\
82 \\
54 \cdot 6(9 \cdot 3) \\
11 \\
0^{\star} \\
4 \\
133 \cdot 1(28 \cdot 2) \\
85 \cdot 3(17 \cdot 2) \\
72 \cdot 9(15 \cdot 2) \\
9 \cdot 2(0 \cdot 9) \\
0 \cdot 44(0 \cdot 04) \\
249(105)\end{array}$ & $\begin{array}{l}150 \\
85 \\
54 \cdot 5(8 \cdot 9) \\
6 \\
6^{\star} \\
2 \\
133 \cdot 3(27 \cdot 1) \\
87 \cdot 8(17 \cdot 5) \\
73 \cdot 1(17 \cdot 2) \\
9 \cdot 2(0 \cdot 9) \\
0 \cdot 44(0 \cdot 04) \\
245(96)\end{array}$ \\
\hline
\end{tabular}

angiogram was then obtained and left ventricular pressures were recorded. The arterial catheter was removed and the femoral artery introducer sheath remained in place for 24-48 hours.

A Swan-Ganz catheter was introduced by femoral (only in the streptokinase patients), subclavian, jugular, or brachial vein puncture by a French 8 introducer sheath and the catheter remained in the pulmonary artery for 24 to $\mathbf{4 8}$ hours. Heparin infusion of 10000-20000 units per 24 hours and coumadin were started in the coronary care unit. Heparin infusion was stopped when the partial thromboplastin time exceeded $120 \mathrm{sec}$.

Patients in the control group underwent conventional treatment and had haemodynamic monitoring with a Swan-Ganz catheter in the same way as the patients in the streptokinase group. Anticoagulation with heparin and coumadin was identical to that given to patients in the streptokinase group. In 13 patients (9\%) allocated to streptokinase treatment, catheterisation was not performed because of technical difficulties or because the patient refused. Three patients $(2 \%)$ allocated to conventional treatment had intracoronary infusion of streptokinase during the acute phase. The results were analysed on the basis of intention to treat.

Venous blood samples were taken at admission and at $3,6,12,18,24,36$, and 48 hours after admission for laboratory tests including haemoglobin concentration and haematocrit. Standard medical care, including analgesics, diuretics, and inotropic support, was given to all patients. ${ }^{10}$ The occurrence of bleeding, thrombosis, pulmonary embolism, recurrent angina and infarction or both, left ventricular failure, and arrhythmias was recorded. Blood transfusions were given according to the instructions of the consulting physicians. Haemoglobin concentrations which were below $7.0 \mathrm{mmol} / 1(11.2 \mathrm{~g} / \mathrm{dl})$ at admission or during the first 48 hours after acute myocardial infarction were regarded as an indication for blood transfusion.

Bleeding was defined as the occurrence of haematoma, haemoptysis, haematemesis, melaena, haematuria, or an intracranial event within $\mathbf{4 8}$ hours of admission. Swelling was regarded as an essential feature of the diagnosis of haematoma at the puncture site. To estimate the change in haematocrit during routine heart catheterisation, we studied 43 other patients, aged $\leqslant 70$ years, undergoing elective coronary angiography and left ventricular cineangiography because of chest pain. The haematocrit was determined 24 hours before and 24 hours after the procedure. The arterial catheterisation procedure was identical to the procedure used in the study, except that streptokinase, acetylsalicylic acid, and hydrocortisone were not infused. The arterial 
catheter sheath was removed immediately after the patients had received $50 \mathrm{mg}$ of protamine sulphate intravenously.

\section{STATISTICAL ANALYSIS}

The results were analysed by Student's $t$ test for either unpaired or paired data, or by the $\chi^{2}$ test for frequency distribution analysis.

\section{Results}

\section{CHARACTERISTICS OF PATIENTS BEFORE RANDOMISATION}

Apart from the more frequent use of anti-platelet drugs in the control group there were no signficant differences between the two groups before randomisation (Table 1).

\section{BLEEDING, SITE OF BLEEDING, AND}

TRANSFUSION REQUIREMENT

Twenty four patients $(16 \%)$ in the streptokinase group had manifest bleeding which caused groin haematomas in all of them. None of this group had bleeding at other sites. Two patients $(1 \%)$ on conventional treatment had bleeding-one groin haematoma and one haematoma at a venepuncture site on the forearm. There were no deaths from bleeding in either group. Patients in the streptokinase group needed 66 units of packed cells compared with 17 units in the control group $(p<0.0001)$. In the streptokinase group 50 units of packed cells were given to patients with manifest bleeding (16 patients) and 16 units to patients without manifest bleeding (eight patients). Analysis of the characteristics of all patients before randomisation (Table 1 ) in relation to these results showed that only age was of predictive value. There was bleeding in $15(28 \%)$ of the 53 patients aged $\geqslant 60$. Only nine $(10 \%)$ of those aged $<60$ had bleeding complications. Thirty two per cent of the patients with bleeding complications and $16 \%$ of those without were female. This difference is not statistically significant. The control group required transfusions of 17 units of packed cells to eight patients including one with manifest bleeding. Table 2 summarises these results.

\section{FALL IN HAEMATOCRIT}

We excluded results from 98 patients (56 allocated to streptokinase and 42 to conventional treatment) from the analysis because haematocrit values were missing at admission or during the first $\mathbf{4 8}$ hours (82 cases), because patients allocated to streptokinase had received conventional treatment (13 cases), and because intracoronary streptokinase had been given to three conventionally treated patients. Haematocrits at entry and the lowest values observed in the first 48 hours after entry were recorded in the remaining 204 patients (97 in the treated group and 107 in the controls). Characteristics before randomisation were no different in this subgroup than in the total group as defined in Table 1 . The mean (SD) fall in haematocrit was $0.05(0.04)$ in the streptokinase treated group and $0.03(0.04)$ in the conventionally treated group.

Table 3 shows the characteristics, the dose of streptokinase, and the fall in haematocrit in these patients in relation to bleeding complications. There were no differences in the characteristics before randomisation among the three groups. As expected, in the streptokinase group there was a larger fall in haematocrit in the patients with manifest bleeding than in those without. The fall in haematocrit in the latter group, however, is still significantly higher than in the controls, indicating that there may have been occult bleeding without manifest bleeding in the streptokinase treated patients. The dose of streptokinase was similar in patients with manifest bleeding complications and in those without.

\section{SYSTEMIC FIBRINOLYSIS}

Venous fibrinogen concentrations were measured before and immediately after intracoronary streptokinase infusion in 24 patients in the streptokinase group (four patients with and 20 without manifest bleeding). Systemic fibrinolysis was judged to have occurred when the fibrinogen concentration

Table 2 Frequency of bleeding and transfusion requirement in all patients

\begin{tabular}{|c|c|c|c|c|}
\hline & \multicolumn{2}{|l|}{ Streptokinase } & \multicolumn{2}{|l|}{ Control } \\
\hline & Bleeding & Non-bleeding & Bleeding & Non-bleeding \\
\hline $\begin{array}{l}\text { No of patients } \\
\text { Sex (\% male) } \\
\text { Age over } 60 \text { years } \\
\text { Transfusions (units) } \\
\text { Patients transfused }\end{array}$ & $\begin{array}{l}24^{\star} \\
71 \\
15(63 \%)^{\star \star \star} \\
50^{\star \star} \\
16(67 \%)\end{array}$ & $\begin{array}{l}128 \\
84 \\
38(30 \%) \\
16 \\
8(6 \%)\end{array}$ & $\begin{array}{l}2 \\
0 \\
2(100 \%) \\
4 \\
1(50 \%)\end{array}$ & $\begin{array}{l}148 \\
86 \\
37(25 \%) \\
13 \\
7(5 \%)\end{array}$ \\
\hline
\end{tabular}

$\star_{p}<0.0001$, vs control group.

${ }_{\star \star \star} \mathrm{p}<0.01$, vs control group.

$\star \star \star \mathrm{p}<0.01$, vs non-bleeders in the streptokinase group. 
Table 3 Fall in haematocrit, dose of streptokinase, and transfusion support in 204 patients (mean (SD))

\begin{tabular}{llll}
\hline & \multicolumn{2}{l}{ Streptokinase group } & Controls \\
\cline { 2 - 4 } & Bleeding & Non-bleeding & \\
\hline No of patients & 18 & 79 & 107 \\
Baseline haematocrit & $0 \cdot 42(0.02)$ & $0 \cdot 45(0.04)$ & $0.44(0.04)$ \\
Fall in haematocrit & $0 \cdot 07(0.04)$ & $0.05(0.04)$ & $0.03(0.04)$ \\
Dose of streptokinase $\left(\times 10^{3}\right.$ units) & $234(58)$ & $218(80)$ & 0 \\
Transfusions (units) & $40(61 \%)$ & $3(4 \%)$ & 11 \\
Patients transfused (no) & $11(61 \%)$ & $6(6 \%)$ \\
\hline
\end{tabular}

${ }^{\star} \mathrm{p}<0.001$ vs control group.

dropped to $50 \%$ or less of the original value.

Systemic fibrinolysis occurred in $19(79 \%)$ of the 24 patients tested. The fall in haematocrit $(0.05(0.03))$ in the patients without systemic fibrinolysis was greater than the fall in those with fibrinolysis $(0.01(0.03), p<0.05)$. There was manifest bleeding in four patients $(21 \%)$ with systemic fibrinolysis and in none of the patients without systemic fibrinolysis.

\section{DOSE OF INTRACORONARY STREPTOKINASE} AND FALL IN HAEMATOCRIT

There was no correlation between the dose of intracoronary streptokinase given to the 97 patients shown in Table 3 and the fall in haematocrit (Figure).

\section{HAEMATOCRIT BEFORE AND AFTER ELECTIVE CATHETERISATION}

There was no change in haematocrit in patients

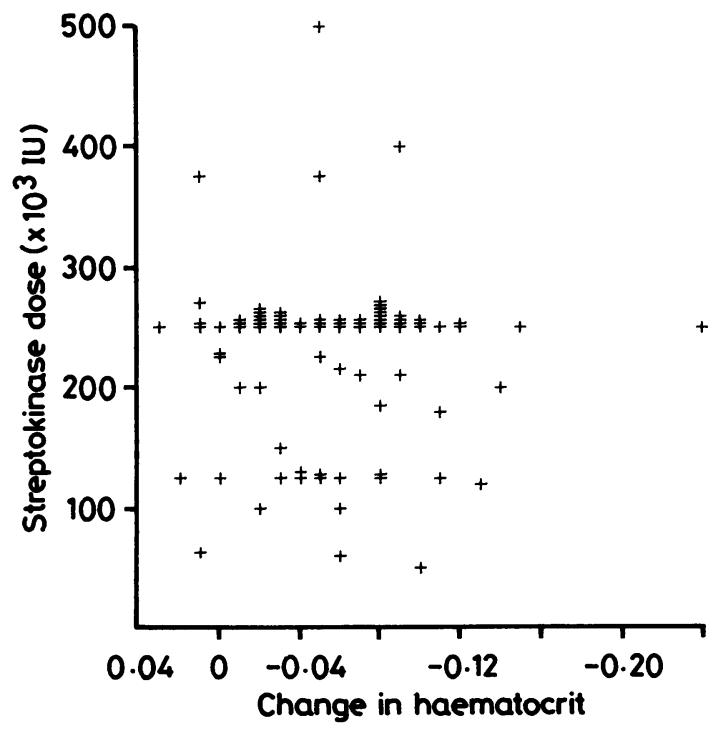

Figure Fall in haematocrit and dose of intracoronary streptokinase in 97 patients. undergoing elective heart catheterisation $(0.45(0.02)$ before and $0.45(0.04) 24$ hours after catheterisation).

\section{Discussion}

Although controlled trials have not confirmed the efficacy of intravenous streptokinase treatment in acute myocardial infarction, ${ }^{112}$ they have shown that a dose of 2.5 million units in 24 hours may safely be given. There were reports of non-fatal bleeding complications in $0-25 \%$ of patients but they did not require transfusion. ${ }^{11-13}$ The effective intracoronary dose of streptokinase is quite low but arterial puncture and instrumentation themselves increase the risk of bleeding. The reported frequency of haemorrhagic complications associated with intracoronary streptokinase varies from $0 \%$ to $23 \% \cdot{ }^{341415}$ Isolated reports of bleeding after intracoronary streptokinase ${ }^{16}$ may merely reflect normal complications of myocardial infarction. Haemorrhagic infarction ${ }^{1718}$ with or without ventricular rupture can occur without fibrinolytic treatment.

We found bleeding in $16 \%$ of patients treated with intracoronary streptokinase. Bleeding occurred exclusively at the femoral puncture site and substantial transfusion support was necessary. Bleeding resulted in a large drop in haematocrit.

The haematocrit usually falls to 0.02 in the first few days after acute myocardial infarction. ${ }^{19}$ But the fall in patients treated with streptokinase (even in those without manifest bleeding) was significantly higher than that in the control group. This suggests that there was occult bleeding in the group given streptokinase. Such bleeding is minor, of unknown origin, and has no clinical consequences. It is not the result of standard anticoagulation (intravenous heparin and oral coumadin), since control patients on the same regimen had a significantly smaller fall in haematocrit. Nor can it be attributed to venous catheterisation because most patients had this procedure. Furthermore arterial catheterisation per se does not necessarily cause a drop in haematocrit, since in our hands elective catheterisation did not 
change haematocrit. Though it is a time consuming procedure that is unpleasant for the patient, there are likely to be benefits associated with the low dose of streptokinase used in selective infusion. Systemic fibrinolysis, however, is often seen in intracoronary streptokinase treatment ${ }^{6-8}$ as well as in intravenous streptokinase infusion, and this complication has even been correlated with the success of the procedure. ${ }^{20-22} \mathrm{We}$ found systemic fibrinolysis in $80 \%$ of patients screened. The fall in haematocrit was higher in patients with systemic fibrinolysis than in those without. This confirms the correlation between bleeding and systemic fibrinolysis. ${ }^{14}$ Bleeding in patients undergoing intracoronary streptokinase infusion was apparently caused by streptokinase induced systemic fibrinolysis together with the arterial catheterisation and the use of intravenous acetylsalicylic acid and hydrocortisone. Bleeding was not related to the dose of streptokinase given, as has already been shown by others. ${ }^{14}$

\section{CLINICAL IMPLICATIONS}

There is a definite risk of non-fatal major arterial bleeding associated with intracoronary streptokinase treatment. This is attributable to the combined use of streptokinase with a catheterisation procedure. Bleeding was three times more common in patients over the age of 60 than in younger patients and tended to be more common in females. The appearance of a groin haematoma after intracoronary streptokinase treatment indicates important bleeding and transfusion support was required by about $70 \%$ of patients with this complication. The use of more specific fibrinolytic agents such as tissue plasminogen activator, ${ }^{23}$ might avoid these complications.

\section{References}

1 Fletcher AP, Sherry S, Alkjaersig N, Smyrniotis FE, Jick S. The maintenance of a sustained thrombolytic state in man. II. Clinical observations on patients with myocardial infarction and other thromboembolic disorders. f Clin Invest 1959; 38: 1111-9.

2 Urokinase-Streptokinase Pulmonary Embolism Trial Study Group. Urokinase-streptokinase embolism trial. Phase II results. $\mathcal{F} A M A$ 1974; 229: 1606-13.

3 Anderson JL, Marshall HW, Bray BE, et al. A randomized trial of intracoronary streptokinase in the treatment of acute myocardial infarction. $N$ Engl f Med 1983; 308: 1312-8.

4 Kennedy JW, Ritchie JL, Davis KB, Fritz JK. Western Washington randomized trial of intracoronary streptokinase in acute myocardial infarction. $N$ Engl $₹$ Med 1983; 309: 1477-82.
5 De Feyter PJ, van Eenige MJ, van der Wall EE, et al. Effects of spontaneous and streptokinase-induced recanalization on left ventricular function after myocardial infarction. Circulation 1983; 67: 1039-44.

6 Tabari KK, Rubinstein MD, Robinson MC, Hanson JA. Systemic fibrinolysis associated with intracoronary streptokinase infusion [Abstract]. Am $\mathcal{F}$ Cardiol 1982; 49: 974.

7 Mandelkorn J, Wolf NM, Singh S, Bentivoglio L, Meister SG. Systemic thrombolytic effect of intracoronary streptokinase [Abstract]. Circulation 1981; 64 (suppl IV): 191.

8 Cowley M, Hastillo A, Vetrovec G, Hess ML. Fibrinolytic effects of low dose intracoronary streptokinase administration in acute myocardial infarction [Abstract]. Circulation 1981; 64 (suppl IV): 10.

9 Graor RA, Risius B, Young JR, et al. Low-dose streptokinase for selective thrombolysis: systemic effects and complications. Radiology 1984; 152: 35-9.

10 Simoons ML, Serruys PW, Fioretti P, van den Brand M, Hugenholtz PG. Practical guidelines for treatment with betablockers and nitrates in patients with acute myocardial infarction. Eur Heart f 1983; 4 (suppl D): 129-35.

11 European Cooperative Study Group for Streptokinase Treatment in Acute Myocardial Infarction. Streptokinase in acute myocardial infarction. N Engl f Med 1979; 301: 797-802.

12 Aber CP, Bass NM, Berry CL, et al. Streptokinase in acute myocardial infarction: a controlled multicentre study in the United Kingdom. Br Med F 1976; 2: 1100-4.

13 Spann JF, Sherry S, Carabello BA, et al. Coronary thrombolysis by intravenous streptokinase in acute myocardial infarction: acute and follow-up studies. $\operatorname{Am} \mathcal{F}$ Cardiol 1984; 53: 655-61.

14 Timmis GC, Gangadharan V, Ramos RG, et al. Hemorrhage and the products of fibrinogen digestion after intracoronary administration of streptokinase. Circulation 1984; 69: 1146-52.

15 Weinstein J. Treatment of myocardial infarction with intracoronary streptokinase: efficacy and safety data from 209 United States cases in the Hoechst-Roussel registry. Am Heart $\mathcal{F} 1982$; 104: 894-8.

16 Singh S, Ptacin MJ, Bamrah VS. Spontaneous mediastinal hemorrhage. A complication of intracoronary streptokinase infusion for coronary thrombosis. Arch Intern Med 1983; 143: 562-3.

17 Kao KJ, Hackel DB, Kong Y. Hemorrhagic myocardial infarction after streptokinase treatment for acute coronary thrombosis. Arch Pathol Lab Med 1984; 108: 121-4.

18 Mathey DG, Schofer J, Kuck KH, Beil U, Kloeppel G. Transmural, haemorrhagic myocardial infarction after intracoronary streptokinase. Clinical, angiographic, and necropsy findings. $\mathrm{Br}$ Heart $\mathcal{F}$ 1982; 48: 546-51.

19 Jan K, Chien S, Bigger JT Jr. Observation on blood viscosity changes after acute myocardial infarction. Circulation 1975; 51: $1079-84$.

20 Alderman EL, Jutzy KR, Berte LE, et al. Randomized comparison of intravenous versus intracoronary streptokinase for myocardial infarction. Am $\mathcal{f}$ Cardiol 1984; 54: 14-9.

21 Rothbard RL, Fitzpatrick PG, Caton DM, Francis CW, Hood WB Jr, Marder VJ. Relationship of systemic lytic state to successful reperfusion with standard and low-dose intracoronary streptokinase. Circulation 1985; 71: 562-70.

22 Verheugt FWA, Res JCJ, Van de Berg TAM, Huijgens PC, Roos JP. Success of intracoronary streptokinase infusion in acute myocardial infarction is associated with systemic fibrinolysis [Abstract]. Proceedings of the Eighth Asian Pacific Cardiology Congress, Taipei, Taiwan, November, 1983: 80.

23 TIMI Study Group. The thrombocysis in myocardiol infarction (TIMI trial). $N$ Engl f Med 1985; 312: 932-6. 